\title{
Improved Shoot Organogenesis from Leaf Explants of Highbush Blueberry
}

\author{
X. Cao ${ }^{1}$ and F.A. Hammerschlag ${ }^{2}$ \\ Fruit Laboratory, Agricultural Research Service, U.S. Department of \\ Agriculture, 10300 Baltimore Avenue, Beltsville, MD 20705
}

Additional index words. Ericaceae, photosynthetic photon flux, shoot regeneration, thidiazuron, tissue culture, Vaccinium corymbosum, zeatin riboside

\begin{abstract}
As part of a program to develop transgenic highbush blueberry (Vaccinium corymbosum $\mathbf{L}$.) cultivars, studies were conducted to determine optimum conditions for high efficiency shoot regeneration from leaf explants of shoots propagated in vitro. The effects on shoot organogenesis of age of explant source, length of dark treatment, the addition of either thidiazuron (TDZ) at 1 or $5 \mu \mathrm{M}$, or zeatin riboside at $20 \mu \mathrm{M}$ to the regeneration medium, and a photosynthetic photon flux $(P P F)$ of either $18 \pm 5$ or $55 \pm 5$ $\mu \mathrm{mol} \cdot \mathrm{m}^{-2} \cdot \mathrm{s}^{-1}$ were investigated. A maximum of 13.0, 13.0, 12.6, and 4.6 shoots regenerating per explant for cultivars Duke, Georgiagem, Sierra, and Jersey, respectively, occurred on regeneration medium with zeatin riboside and under a $P P F$ of $55 \pm 5$ $\mu \mathrm{mol} \cdot \mathrm{m}^{-2} \cdot \mathrm{s}^{-1}$. 'Duke' regenerated equally well on medium with either zeatin riboside or $1 \mu \mathrm{M}$ TDZ, whereas the number of shoots per explant for 'Georgiagem' and 'Sierra' was significantly higher on zeatin riboside. Regeneration of 'Duke', 'Jersey', and 'Sierra' on zeatin riboside was significantly better under a $P P F$ of $55 \pm 5 \mu \mathrm{mol} \cdot \mathrm{m}^{-2} \cdot \mathrm{s}^{-1}$ than under 18 $\pm 5 \mu \mathrm{mol} \cdot \mathrm{m}^{-2} \cdot \mathrm{s}^{-1}$, but the higher $P P F$ inhibited regeneration of 'Duke' on $5 \mu \mathrm{M}$ TDZ. There were no significant differences in percentage of regeneration or the number of shoots per explant from leaf explants derived from either 1-, 2-, or 3-week-old shoot cultures, or when either 1 week or 2 weeks of darkness preceded light treatments. Chemical names used: 1-phenyl-3-(1,2,3-thiadiazol-5-yl)urea (thidiazuron, TDZ); 9-(- $\beta$-ribofuranosyl)6-(4-hydroxy-3-methyl-but-2-enylamino)purine (zeatin riboside).
\end{abstract}

Highbush blueberry is a good candidate for gene transfer studies because high heterozygosity and polyploidy impede improvement by traditional breeding methods. Improvement via genetic engineering, however, depends on an efficient gene delivery system, a system for selection, and high frequency shoot regeneration via either organogenesis or somatic embryogenesis. Only a few reports exist of shoot organogenesis from leaf explants of commercially important cultivars of highbush blueberry (Billings et al., 1988; Callow et al., 1989; Rowland and Ogden, 1992), and these studies focused on plant growth regulator and genotype effects. Billings et al. (1988) achieved maximum regeneration frequencies of seven shoots per explant for 'Berkeley' and 10 for 'Bluehaven'. Callow et al. (1989) achieved regeneration frequencies of only one shoot per explant for 'Bluecrop'. For both studies,

Received for publication 6 July 1999. Accepted for publication 19 Nov. 1999 We thank L. Douglass for assistance with statistical analyses. Use of a company or product name does not imply approval or recommendation of the product to the exclusion of others, which may also be suitable. The cost of publishing this paper was defrayed in part by the payment of page charges. Under postal regulations, this paper therefore must be hereby marked advertisement solely to indicate this fact.

${ }^{1}$ Visiting Research Horticulturist; Shaanxi Fruit Crops Research Center, 20 Dong-Yi Road, Xian, Shaanxi, 710061, Peoples Republic of China.

${ }^{2}$ Research Plant Physiologist. To whom reprint requests should be addressed. E-mail address: fhammers@asrr.arsusda.gov regeneration media contained the cytokinin 6$(\gamma, \gamma$-dimethylallylamino)-purine (2iP) and explants were incubated under a photosynthetic photon flux $(P P F)$ of $<40 \mu \mathrm{mol} \cdot \mathrm{m}^{-2} \cdot \mathrm{s}^{-1}$. More recently, Rowland and Ogden (1992) demonstrated that the cytokinin conjugate zeatin riboside (ZR) was more effective for shoot regeneration than either zeatin or $2 \mathrm{iP}$. They induced a maximum regeneration of 20 shoots per leaf explant for 'Sunrise' under a $P P F$ of 20-25 $\mathrm{mol} \cdot \mathrm{m}^{-2} \cdot \mathrm{s}^{-1}$, but were unable to induce shoot regeneration from 'Bluecrop' and 'Duke'.

Factors such as age of explant source, age of explant, presence of the cytokinin-like compound thidiazuron (TDZ), type of gelling agent, length of dark treatment, and $P P F$ have significant effects on adventitious shoot formation from leaf explants of woody plant species (Hammerschlag and Litz, 1992; Huetteman and Preece, 1993; Murthy et al., 1998). The objective of this study was to investigate the effects of age of the explant source, length of dark period, TDZ vs. ZR, and $P P F$ on regeneration of shoots from leaf explants of several commercially important highbush blueberry cultivars.

\section{Materials and Methods}

Plant material and medium. Leaf-blade explants were dissected from 1-, 2-, and 3week-old, in vitro-cultured shoots of northern highbush blueberry cultivars Bluecrop, Duke, Jersey, and Sierra and the southern highbush (V.×corymbosum) cultivar Georgiagem. Donor shoot cultures were maintained by transferring 1-2-cm-long axillary shoots at 4-week intervals onto $42.5 \mathrm{~mL}$ of blueberry shoot multiplication medium (Rowland and Ogden, 1992), consisting of Woody Plant Medium (Lloyd and McCown, 1980) modified as follows $\left(\mathrm{mg} \cdot \mathrm{L}^{-1}\right)$ : $684 \mathrm{Ca}\left(\mathrm{NO}_{3}\right)_{2} \cdot 4 \mathrm{H}_{2} \mathrm{O}, 190$ $\mathrm{KNO}_{3}, 73.4 \quad \mathrm{C}_{10} \mathrm{H}_{13} \mathrm{FeN}_{2} \mathrm{NaO}_{8}$ [EDTA; (ethylenedinitrilo)-tetraacetic acid ferricsodium salt] (Sigma, St. Louis), and 0.1 thiamine $\cdot \mathrm{HCl}$, and without $\mathrm{K}_{2} \mathrm{SO}_{4}, \mathrm{CaCl}_{2}$, $\mathrm{FeSO}_{4}$, and $\mathrm{Na}_{2}$ EDTA. The medium also contained $15 \mathrm{~mm}$ sucrose, Difco Bacto-agar $\left(5.5 \mathrm{~g} \cdot \mathrm{L}^{-1}\right), 24.6 \mu \mathrm{m} 2 \mathrm{iP}$ and $9.1 \mu \mathrm{m}$ zeatin. The $\mathrm{pH}$ was adjusted to 5.2 before autoclaving at $121^{\circ} \mathrm{C}$ at $131 \mathrm{kPa}$ for $15 \mathrm{~min}$; the medium was then dispensed into glass jars that were sealed with plastic wrap. Shoot cultures were incubated at $23{ }^{\circ} \mathrm{C}$ under a 16 -h photoperiod provided by cool-white fluorescent lights at a $P P F$ of $40 \mu \mathrm{mol} \cdot \mathrm{m}^{-2} \cdot \mathrm{s}^{-1}$.

Shoot organogenesis. Leaf explants from tissue-cultured shoots (1-, 2-, and 3-week-old shoot cultures) were prepared from two or three of the youngest, fully expanded leaves by dissecting perpendicular to the midrib to remove the petiole and the distal one-third of the blade. The remainder of the leaf blade was placed abaxial side up on the surface of $20 \mathrm{~mL}$ of shoot regeneration medium in $100 \times 15$-mm petri dishes (sealed with plastic wrap). The shoot regeneration media differed from the shoot propagation medium (see above), only containing either 1 or $5 \mu \mathrm{M}$ TDZ, or $20 \mu \mathrm{M} Z \mathrm{R}$, instead of $2 \mathrm{iP}$ and zeatin. Preliminary studies (data not shown) indicated that 10 or $20 \mu \mathrm{M}$ TDZ induced no notable regeneration, so these concentrations of TDZ were not included in this study. The shoot elongation medium was the same as the shoot propagation medium, but without growth regulators. Explants were incubated in the dark for either 1 or 2 weeks at $23{ }^{\circ} \mathrm{C}$, and then incubated under a 16-h photoperiod provided by cool-white fluorescent lights at a $P P F$ of either $18 \pm 5 \mu \mathrm{mol} \cdot \mathrm{m}^{-2} \cdot \mathrm{s}^{-1}$ or $55 \pm 5$ $\mu \mathrm{mol} \cdot \mathrm{m}^{-2} \cdot \mathrm{s}^{-1}$. Explants were subcultured every 2 weeks. After 6 weeks, explants were placed on shoot elongation medium for $10 \mathrm{~d}$ and then scored for percentage of regeneration and number of shoots per explant.

Experimental design and statistical analyses. Petri dishes were arranged in a completely randomized design under each $P P F$ treatment. Regeneration experiments were replicated a minimum of three times with two petri dishes (five leaf explants per petri dish) per treatment per replication. Because most of the percentage of regeneration data for the $P P F$ and growth regulator treatments did not differ among cultivars, only data for number of shoots per explant were analyzed using SAS, version 6.12, mixed model analysis of variance procedure (SAS Institute, 1997). Differences among treatment means were tested using the least significant difference (LSD) test, $P \leq 0.05$.

\section{Results and Discussion}

Influence of the age of the explant source and time of incubation in darkness. Neither the age of the shoot cultures nor the time held in 
darkness significantly influenced efficiency of blueberry shoot regeneration (data not shown). In other studies with perennial fruit crop species, both age of explant source (Druart, 1990; Nehra et al., 1989) and length of time in darkness (Fasolo et al., 1989; Hsia and Korban, 1998; Korban etal., 1992; Predieri and Malavasi, 1989) significantly affected shoot regeneration frequency. Although not important in the present study, the age of the explant source either promoted or inhibited the efficiency of transformation, depending on the cultivar of highbush blueberry (Cao et al., 1998).

Influence of TDZ and $Z R$. Although concentrations of TDZ from 0.1 to $20 \mu \mathrm{M}$ stimulate shoot organogenesis from leaves of woody species (Huetteman and Preece, 1993), we used a lower concentration range for TDZ than for ZR in the present study because concentrations of TDZ higher than $5 \mu \mathrm{M}$ inhibited shoot regeneration in our preliminary studies (data not shown), and because TDZ is active at lower concentrations than are the amino purine cytokinins (Mok et al., 1987). In two of four cultivars, the cytokinin influenced the percentage of regeneration (Table 1). Percentage of regeneration was similar on TDZ and ZR for 'Duke' and 'Sierra'; however, percentage of regeneration for 'Georgiagem' was reduced from $100 \%$ on $\mathrm{ZR}$ to $25 \%$ to $58 \%$ on TDZ; and for 'Jersey', from $56 \%$ to $100 \%$ on ZR to $45 \%$ to $65 \%$ on TDZ (Table 1 ). The type of cytokinin also influenced the number of shoots produced per explant (Fig. 1); the number was significantly less $(P \leq 0.05)$ on TDZ than on ZR for most cultivars; however, these differences were influenced by $P P F$ (Fig. 1). Under a low $P P F$ of $18 \pm 5 \mu \mathrm{mol} \cdot \mathrm{m}^{-2} \cdot \mathrm{s}^{-1}$, 'Duke' and 'Sierra' produced significantly more shoots per explant on $5 \mu \mathrm{M}$ TDZ than on ZR (Fig. 1, top); however, under a high $P P F$ of $55 \pm 5 \mu \mathrm{mol} \cdot \mathrm{m}^{-2} \cdot \mathrm{s}^{-1}$, 'Duke', 'Georgiagem', 'Jersey', and 'Sierra' produced significantly more shoots per explant on ZR than on $5 \mu \mathrm{M}$ TDZ (Fig. 1, bottom).

Among cytokinins and cytokinin-like compounds, TDZ is an attractive candidate for plant regeneration studies, because it is less expensive than either $2 \mathrm{iP}$ or $\mathrm{ZR}$ (Hsia and

Table 1. Effect of TDZ, ZR, and two PPF levels on percentage of shoot regeneration from leaf explants of four highbush blueberry cultivars. ${ }^{2}$

\begin{tabular}{|c|c|c|c|}
\hline \multirow[b]{2}{*}{$\underline{\text { Cultivar }}$} & \multicolumn{2}{|c|}{$\operatorname{TDZ}(\mu \mathrm{M})$} & \multirow{2}{*}{$\frac{\mathrm{ZR}(\mu \mathrm{M})}{20}$} \\
\hline & 1 & 5 & \\
\hline \multicolumn{4}{|c|}{$P P F=18 \pm 5$} \\
\hline Duke & $100 \pm 0$ & $100 \pm 0$ & $100 \pm 0$ \\
\hline Georgiagem & $50 \pm 5$ & $58 \pm 5$ & $100 \pm 0$ \\
\hline Jersey & $45 \pm 10$ & $65 \pm 10$ & $56 \pm 13$ \\
\hline Sierra & $100 \pm 0$ & $100 \pm 10$ & $72 \pm 10$ \\
\hline \multicolumn{4}{|c|}{$P P F=55 \pm 5$} \\
\hline Duke & $100 \pm 0$ & $100 \pm 0$ & $100 \pm 0$ \\
\hline Georgiagem & $55 \pm 15$ & $25 \pm 11$ & $100 \pm 0$ \\
\hline Jersey & $50 \pm 7$ & $47 \pm 7$ & $100 \pm 0$ \\
\hline Sierra & $100 \pm 0$ & $100 \pm 0$ & $100 \pm 0$ \\
\hline
\end{tabular}

${ }^{2}$ Each value represents the mean \pm SE of a minimum of three replications with 10 explants per treatment per replication. $\mathrm{TDZ}=$ thidiazuron; $\mathrm{ZR}=$ zeatin riboside; $P P F=$ photosynthetic photon flux $\left(\mu \mathrm{mol} \cdot \mathrm{m}^{-2} \cdot \mathrm{s}^{-1}\right)$
Korban, 1998; Shibli and Smith, 1996), and induces either organogenesis or somatic embryogenesis of many woody fruit crop genera, including Malus (Korban et al., 1992; Van Nieuwkerk et al., 1986), Prunus (Mante et al., 1989), and Rubus (Fiola et al., 1990). Although regeneration frequency (the number of shoots per explant), in general, was highest on media with ZR, our data suggest that $1 \mu \mathrm{M}$ TDZ can replace $20 \mu \mathrm{M} Z \mathrm{ZR}$ in regeneration studies with 'Duke', when explants are incubated under either of the light intensities tested (Table 1, Fig. 1). Studies with ohelo (Vaccinium pahalae Skottsb.) and bilberry (V. myrtillus L.) (Shibli and Smith, 1996) indicated that 0.9-2.7 $\mu \mathrm{M}$ TDZ were more effective than 9.1-27.4 $\mu \mathrm{M}$ zeatin or 19.9-59 $\mu \mathrm{M} 2 \mathrm{iP}$ for inducing shoot regeneration from leaf explants.

Influence of $P P F$. In only four of the 12 comparisons did PPF influence the percentage of regeneration (Table 1). For 'Georgiagem' on $5 \mu \mathrm{M}$ TDZ, the percentage was greater at the lower light intensity, whereas for 'Jersey' and 'Sierra' on ZR, it was greater at the higher light intensity. The $P P F$ significantly influenced the number of shoots per explant within cultivars in five of 15 comparisons; however, the response to $P P F$ was influenced by cytokinin and genotype (Fig. 2). The $P P F$ was not a significant factor with $1 \mu \mathrm{M}$ TDZ (Fig. 2, top); however, with $5 \mu \mathrm{M} \mathrm{TDZ,} \mathrm{the}$ efficiency of shoot regeneration of both 'Duke' and 'Georgiagem' was significantly better at the low than at the high $P P F$ (Fig. 2, middle). For regeneration of cultivars Duke, Jersey, and Sierra on medium with $20 \mu \mathrm{M} Z \mathrm{ZR}$, the opposite was true (Fig. 2, bottom). Maximum regeneration of 'Duke', 'Georgiagem', 'Jersey', and 'Sierra' occurred under a $P P F$ of 55 $\mu \mathrm{mol} \cdot \mathrm{m}^{-2} \cdot \mathrm{s}^{-1}$, and when explants were incubated on medium with $20 \mu \mathrm{M}$ ZR (Figs. 1, bottom, and 2, bottom). A PPF of 40-60 $\mu \mathrm{mol} \cdot \mathrm{m}^{-2} \cdot \mathrm{s}^{-1}$ induced the highest in vitro shoot proliferation and growth of several highbush blueberry cultivars (Noè and Eccher, 1994; Noè et al., 1998). $P P F$ was also an important factor for adventitious shoot formation of other woody species, including evergreen azalea (Rhododendron sp.) (Hsia and Korban, 1998) and apple (Yepes and Aldwinckle, 1994).

Genotype effect. The genotypes in this study differed significantly in their morphogenic potential (Figs. 1 and 2), as reported in other studies on perennial fruit crop species (Hammerschlag and Litz, 1992), including blueberries (Billings et al., 1988; Rowland and Ogden, 1992). Regeneration frequency ranged from 13.0 shoots per explant for 'Duke' and 'Georgiagem' to none for 'Bluecrop'. Significant differences among the genotypes were observed in response to growth regulator (Fig. 1) and to $P P F$ (Fig. 2, middle and bottom).

Rowland and Ogden (1992) were unable to regenerate 'Duke' on $20 \mu \mathrm{M} Z \mathrm{ZR}$, whereas it readily regenerated on $20 \mu \mathrm{MZR}$ in our experiments. This could be due to several factors, such as nature and maturity of the explant, and $P P F$. Regenerative capacity increases from the tip toward the base of the leaf (Welander, 1988; Yepes and Aldwinckle, 1994). We used

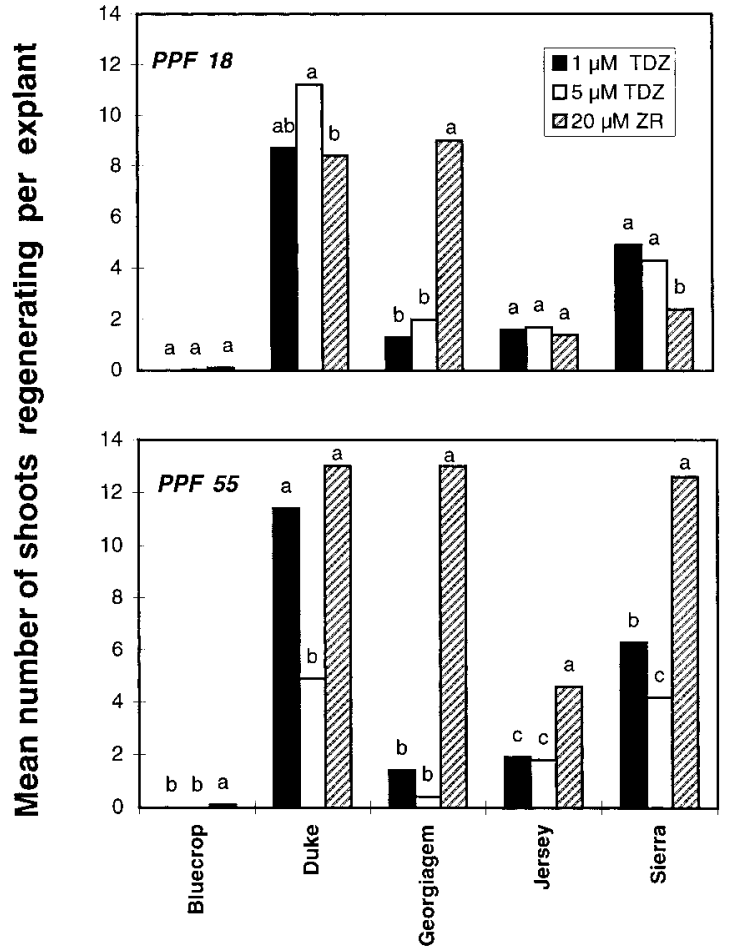

\section{Cultivar}

Fig. 1. Influence of TDZ and ZR on blueberry shoot regeneration from leaf explants grown under either (top) a $P P F$ of $18 \pm 5 \mu \mathrm{mol} \cdot \mathrm{m}^{-2} \cdot \mathrm{s}^{-1}$, or (bottom) a $P P F$ of $55 \pm 5 \mu \mathrm{mol} \cdot \mathrm{m}^{-2} \cdot \mathrm{s}^{-1}$. Mean separation within cultivars and $P P F$ levels by LSD, $P \leq 0.05$. 


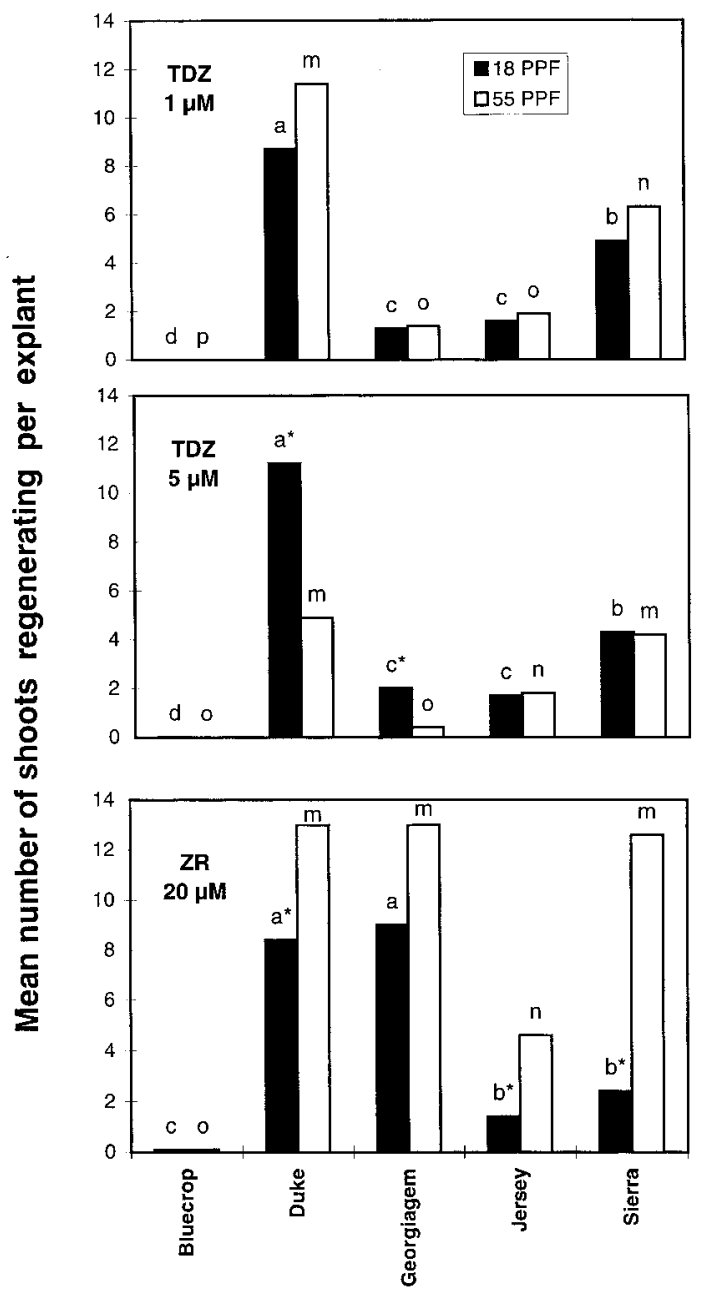

Cultivar

Fig. 2. Influence of $P P F$ on blueberry shoot regeneration from leaf explants on medium with either (top) $1 \mu \mathrm{M}$ TDZ, (middle) $5 \mu_{\mathrm{M}} \mathrm{TDZ}$, or (bottom) $20 \mu_{\mathrm{M}} \mathrm{ZR}$. Mean separation within PPF levels and media by LSD, $P \leq 0.05$. Significant effects of $P P F(P \leq 0.05)$ within cultivars and media are indicated by asterisks.

the basal two-thirds of the leaf blade, whereas Rowland and Ogden (1992) used the middle one-third. Other studies have demonstrated that position of the leaf on the shoot affects shoot regeneration, with young expanding leaves exhibiting a greater morphogenic potential than older, fully expanded leaves (Fasolo et al., 1989; Welander, 1988; Yepes and Aldwinckle, 1994). Rowland and Ogden(1992) used leaf explants from the top to bottom of the shoot; however, only the youngest, fully expanded leaves were used in the present study. Hruskoci and Read (1993) reported regeneration frequencies were higher in younger than in older stem internode segments of blueberry. Finally, Rowland and Ogden (1992) incubated leaves under a low $P P F$ of $20-25 \mu \mathrm{mol} \cdot \mathrm{m}^{-2} \cdot \mathrm{s}^{-1}$. In our study, significantly greater regeneration frequencies were achieved for 'Duke' on ZR under a $P P F$ of $55 \pm 5 \mu \mathrm{mol} \cdot \mathrm{m}^{-2} \cdot \mathrm{s}^{-1}$ than under $18 \pm 5 \mu \mathrm{mol} \cdot \mathrm{m}^{-2} \cdot \mathrm{s}^{-1}$ (Fig. 2, bottom).

In summary, both the type of growth regulator and the level of $P P F$ were significant factors in shoot regeneration from blueberry leaf explants. Given $100 \%$ regeneration and 13 shoots per explant on a medium with $20 \mu \mathrm{M}$
$\mathrm{ZR}$ and under a $P P F$ of $55 \mu \mathrm{mol} \cdot \mathrm{m}^{-2} \cdot \mathrm{s}^{-1}$, it may be possible to use 'Duke', 'Georgiagem', and 'Sierra' in genetic engineering studies.

\section{Literature Cited}

Billings, S.G., C.K. Chin, and G. Jelenkovic. 1988. Regeneration of blueberry plantlets from leaf segments. HortScience 23:763-776.

Callow, P., K. Haghighi, M. Giroux, and J. Hancock. 1989. In vitro shoot regeneration on leaf tissue from micropropagated highbush blueberry. HortScience 24:373-375.

Cao, X., Q. Liu, L.J. Rowland, and F.A. Hammerschlag. 1998. GUS expression in blueberry (Vaccinium sp.): Factors influencing Agrobacterium-mediated gene transfer. Plant Cell Rpt. 18:266-270.

Druart, Ph. 1990. Effect of culture conditions and leaf selection on organogenesis of Malus domestica cv. McIntosh 'Wijcik', and Prunus canescens Bois GM79. Acta Hort. 280:117124.

Fasolo, F., R.H. Zimmerman, and I. Fordham. L. 1989. Adventitious shoot formation on excised leaves of in vitro grown shoots of apple cultivars. Plant Cell Tissue Organ Cult. 16:75-87

Fiola, J.A., M.A. Hassan, H.J. Swartz, R.H. Bors, and R. McNicol. 1990. Effect of thidiazuron, light fluence rates and kanamycin on in vitro shoot organogenesis from excised Rubus cotyledons and leaves. Plant Cell Tissue Organ Cult. 20:223-228.

Hammerschlag, F.A. and R.E. Litz. 1992. Biotechnology of perennial fruit crops. CAB Intl., Wallingford. U.K.

Hruskoci, J.D. and P.E. Read. 1993. In vitro shoot regeneration from internode segments and internode-derived callus of blueberry (Vaccinium spp.). Acta Hort. 346:127-132.

Hsia, C. and S.S. Korban. 1998. Effect of growth regulators, dark treatment and light intensity on shoot organogenesis from leaf tissue of evergreen azalea. J. Hort. Sci. Biotechnol. 73:53-60.

Huetteman, C.A. and J.E. Preece. 1993. Thidiazuron: A potent cytokinin for woody plant tissue culture. Plant Cell Tissue Organ Cult. 33:105-119.

Korban, S.S., P.A. O'Connor, and A. Elobeidy. 1992. Effects of thidiazuron, naphthaleneacetic acid, dark incubation and genotype on shoot organogenesis from Malus leaves. J. Hort. Sci. 67:341-349.

Lloyd, G. and B. McCown. 1980. Commercially feasible micropropagation of mountain laurel, Kalmia latifolia, by use of shoot tip culture. Comb. Proc. Intl. Plant Prop. Soc. 30:421-427

Mante, S. R., Scorza, and J.M. Cordts. 1989. Plant regeneration from cotyledons of Prunus persica. Plant Cell Tissue Organ Cult. 19:1-11.

Mok, M.C., D.W.S. Mok, J.E. Turner, and C.V. Mujer. 1987. Biological and biochemical effects of cytokinin-active phenylurea derivatives in tissue culture systems. HortScience 22:1194-1196.

Murthy, B.N., S.J. Murch, and P. D. Saxena. 1998. Thidiazuron: A potent regulator of in vitro plant morphogenesis. In Vitro Cell. Dev. Biol.-Plant 34:267-275.

Nehra, N.S., C. Stushnoff, and K.K. Kartha. 1989. Direct shoot regeneration from strawberry leaf disks. J. Amer. Soc. Hort. Sci. 114:1014-1018.

Noè, N. and T. Eccher. 1994. Influence of irradiance on in vitro growth and proliferation of Vaccinium corymbosum (highbush blueberry) and subsequent rooting in vivo. Physiol. Plant. 91:273275 .

Noè, N., T. Eccher, E. Del Signore, and A. Montoldi. 1998. Growth and proliferation in vitro of Vaccinium corymbosum under different irradiance and radiation spectral composition. Biol. Plant. 41:161-167.

Predieri, S. and F.F. Malavasi. 1989. High-frequency shoot regeneration from leaves of the apple rootstock M26 (Malus pumila Mill.). Plant Cell Tissue Organ Cult. 17:133-142.

Rowland, L.J. and E.L. Ogden. 1992. Use of a cytokinin conjugate for efficient shoot regeneration from leaf sections of highbush blueberry. HortScience 27:1127-1129.

SAS Institute. 1997. SAS/STAT guide for personal computers. Ver. 6.12. SAS Inst., Cary, N.C.

Shibli, R.A. and M.A.L. Smith. 1996. Direct shoot regeneration from Vaccinium pahalae (ohelo) and V. myrtillus (bilberry) leaf explants. HortScience 31:1225-1228.

Van Nieuwkerk, J.P., R.H. Zimmerman, and I. Fordham. 1986. Thidiazuron stimulation of apple shoot proliferation in vitro. HortScience 21:516518.

Welander, M. 1988. Plant regeneration from leaf and stem segments of shoots raised in vitro from mature apple trees. J. Plant Physiol. 132:738744.

Yepes, L.M. and H.S. Aldwinckle. 1994. Factors that affect leaf regeneration efficiency in apple, and effect of antibiotics in morphogenesis. Plant Cell Tissue Organ Cult. 37:257-269. 